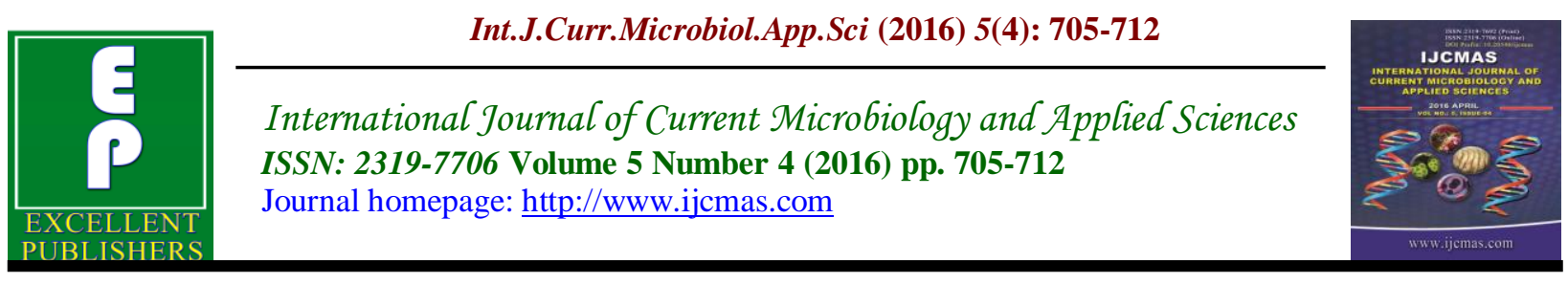

Original Research Article

http://dx.doi.org/10.20546/ijcmas.2016.504.081

\title{
Synthesis, Characterization and Antimicrobial Activity of Ce Doped $\mathrm{TiO}_{2}$ Nanoparticles
}

\author{
Zeeshan Ali ${ }^{1}$, Bharat Raj $^{1}$, M. Vishwas ${ }^{2 *}$ and M. Anisa Athhar ${ }^{1}$ \\ ${ }^{1}$ Department of Microbiology, Government Science College (Autonomous), \\ Bangalore-560001, India \\ ${ }^{2}$ Department of Physics, Government Science College (Autonomous), Bangalore-560001, India \\ *Corresponding author
}

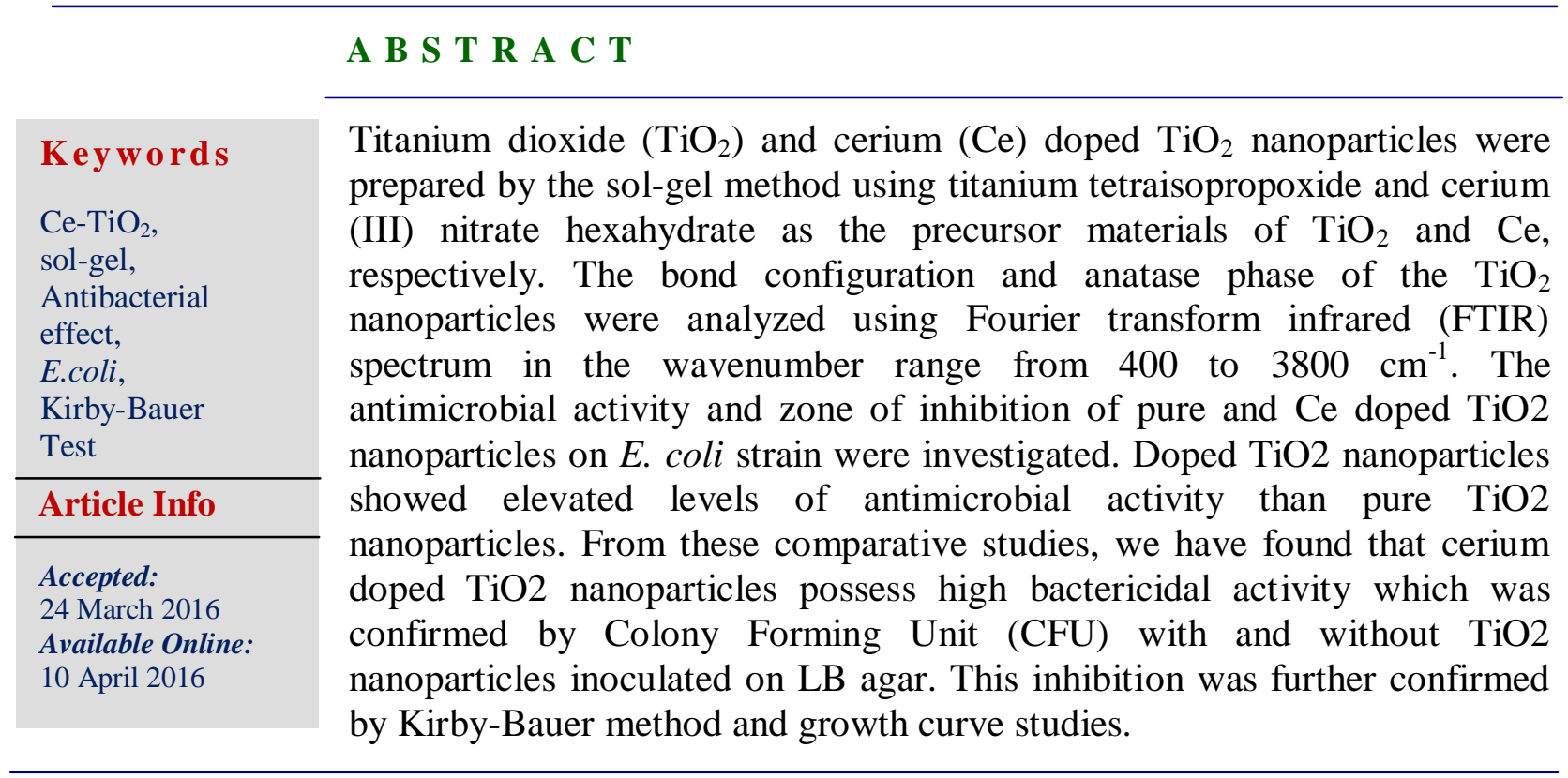

\section{Introduction}

The rapid adaptation of bacteria and resistance to a wide range of antibiotics has led to emergence of different infectious diseases. A curative treatment towards these diseases is becoming a difficult and herculean task. Hence the development of new effective antimicrobials to combat these diseases is essential. Nanotechnology is the engineering of functional systems at the molecular scale. The concepts that seeded nanotechnology were first discussed in 1959 by Richard Feynman. Due to the electronic confinement of nano objects, their optical, chemical, magnetic and antimicrobial properties are different from those of larger objects. The key molecules in biology such as DNA, enzymes, receptors, antigens, antibodies, and oxygen carriers can be included in the dimension of nanometres. Molecular self organization around nanoparticle utilizing the tools of surface science can be of use in the fundamental life processes. In the present era, nanoparticles are found to be a boon for the biomedical research as they possess elevated levels of 
bactericidal activity in treatment of infectious diseases. Hence developing the new agents to inhibit microbial growth is necessary. Metal and metal oxides show potential antimicrobial activity. Metal oxide nanomaterials can be easily prepared by the cost effective sol-gel method (Vishwas et al., 2014; Vishwas et al., 2011; Vishwas et al., 2010; Vishwas et al., 2012) at room temperature. The $\mathrm{TiO} 2$ nanoparticles can be effectively used to decrease the toxicity of bacteria (Kiran Gupta et al., 2013; Razi Ahmad and Meryam Sardar, 2013; Thomas Verdier et al., 2014). Combination therapy with metal nanoparticles has proven to increase the activity of the antibiotics. Bacterial resistance to antibiotics is a major risk factor in the present society. It has lead to the development of such effective antimicrobials which are human and also animal friendly. This has indeed lead to the dissemination of resistant strains of bacteria. Particle size was also an essential parameter which determined the antimicrobial effectiveness of the metal nanoparticles. $\mathrm{TiO} 2$ has three forms: Anatase, rutile and brookite. Among these, anatase is highly unstable, small, isolated and sharply developed crystals and also more commonly occurring modification of $\mathrm{TiO} 2$ as reported by Vishwas et al., 2009. We have preferred the anatase form due to its excellent optical, photo catalytic and antimicrobial properties from size quantization.

\section{Materials and Methods}

Titanium tetraisopropoxide and ethanol were taken in the volume ratio of 1:7 and continuously stirred in a $100 \mathrm{ml}$ beaker for 1h using a magnetic stirrer maintaining temperature of $70^{\circ} \mathrm{C}$. Then $10 \mathrm{ml}$ of deionized water was added drop wise for complete hydrolysis. The solution changed from colorless to white precipitate. The precipitate was filtered using Whatman filter paper and cleaned and dried as reported previously by Vishwas et al., 2014. Ce doped $\mathrm{TiO}_{2}$ nanoparticles were prepared by dissolving 3 wt. \% cerium (III) nitrate hexahydrate $\quad\left[\mathrm{Ce}\left(\mathrm{NO}_{3}\right)_{3} \cdot 6 \mathrm{H}_{2} \mathrm{O}\right]$ (Spectrochem Pvt. Ltd., Mumbai, 99.50\%) in $\mathrm{TiO}_{2}$ sol with continuous stirring and repeated the same procedure of preparation of $\mathrm{TiO}_{2}$ nanoparticles. Ce doped and undoped $\mathrm{TiO}_{2}$ nanoparticles were annealed at $500^{\circ} \mathrm{C}$ for $3 \mathrm{~h}$ in air and subjected to infrared spectral characterization and antibacterial activity.

Eosin methylene blue agar, Luria agar and Luria broth, Pure TiO2, Cerium doped $\mathrm{TiO} 2$, and all other reagents used are of analytical grade.

\section{Preparation of Stock Solution}

Stock solution of $\mathrm{TiO} 2$ nanoparticles (both pure and doped) with concentration of $1 \mathrm{mg} / \mathrm{ml}$ was prepared and suspended in distilled water. The above solution was sonicated for 5 minutes to get a homogeneous suspension and then kept under UV rays for 30 minutes for the activation of nanoparticles. In each experiment, fresh stock solution (sonicated and UV activated) was prepared.

\section{Kirby-Bauer Test}

The antibacterial effect of $\mathrm{TiO}_{2}$ nanoparticles was performed for comparing the inhibition on E.coli by cerium doped and pure $\mathrm{TiO} 2$ nanoparticles. A loopful of E.coli culture was added to $5 \mathrm{ml}$ of Luria broth and incubated for $3 \mathrm{~h}$. About $25 \mathrm{ml}$ of sterile Luria agar was poured into 3 sterile petriplates and allowed to solidify. By spread plate technique, $100 \mu \mathrm{l}$ of inoculum was added on the agar media. Two $10 \mathrm{~mm}$ diameter wells were cut in the agar media. In one well, $50 \mu 1$ of $\mathrm{TiO} 2$ nanoparticles solution was added and in another well, streptomycin was added as control. The 
plate was incubated at $37^{\circ} \mathrm{C}$ for $16 \mathrm{~h}$ and observed for zone of inhibition.

\section{Colony Forming Unit (CFU)}

Six petriplates with different concentrations of $0.2 \mathrm{mg} / \mathrm{ml}, 0.4 \mathrm{mg} / \mathrm{ml}, 0.6 \mathrm{mg} / \mathrm{ml}, 0.8$ $\mathrm{mg} / \mathrm{ml}, 1.0 \mathrm{mg} / \mathrm{ml}$ and one petriplate without $\mathrm{TiO} 2$ nanoparticles was taken as control. $100 \mu \mathrm{l}$ of $10^{-5}$ serially diluted culture was spread on the agar media and incubated for 18-24 hours. Growth was observed and colonies were counted.

\section{Effect of TiO2 in Liquid Media}

Seven $100 \mathrm{ml}$ conical flasks were taken and $60 \mathrm{ml}$ of Luria broth was added and autoclaved. To the conical flasks, $\quad 0.03 \mathrm{mg} / \mathrm{ml}, \quad 0.06 \mathrm{mg} / \mathrm{ml}, \quad 0.13 \mathrm{mg} / \mathrm{ml}$, $\quad 0.25 \mathrm{mg} / \mathrm{ml}, \quad 0.50 \mathrm{mg} / \mathrm{ml}, \quad 1.0 \mathrm{mg} / \mathrm{ml}$ concentrations of $\mathrm{TiO} 2$ was added. One flask without $\mathrm{TiO} 2$ was taken as control. $100 \mu 1$ of inoculum was added and incubated at $37^{\circ} \mathrm{C}$ for 18 hours. Optical Density reading was taken at $600 \mathrm{~nm}$.

\section{Effect of $\mathrm{TiO}_{2}$ in Solid Media}

Luria agar was poured into petriplates in duplicates and allowed to solidify. $100 \mu \mathrm{l}$ of test culture was spread on the surface of agar media. Using cork borer, six wells of $10 \mathrm{~mm}$ diameter were cut and $20 \mu \mathrm{g} / \mathrm{ml}, 40 \mu \mathrm{g} / \mathrm{ml}$, $60 \mu \mathrm{g} / \mathrm{ml}, \quad 80 \mu \mathrm{g} / \mathrm{ml}, \quad 100 \mu \mathrm{g} / \mathrm{ml}$ concentrations of $\mathrm{TiO} 2$ was added. One well without $\mathrm{TiO} 2$ was taken as control and then incubated at $37^{\circ} \mathrm{C}$ for $18 \mathrm{~h}$. Zone of inhibition was measured and tabulated.

\section{Growth Curve Studies}

Six $250 \mathrm{ml}$ conical flasks were taken. 100 $\mathrm{ml}$ Luria broth was added to the flasks and autoclaved. $100 \mu \mathrm{l}$ of freshly grown E.coli culture was added. $200 \mu \mathrm{g} / \mathrm{ml}, 400 \mu \mathrm{g} / \mathrm{ml}$,
$600 \mu \mathrm{g} / \mathrm{ml}, \quad 800 \mu \mathrm{g} / \mathrm{ml}, \quad 1000 \mu \mathrm{g} / \mathrm{ml}$ concentrations of $\mathrm{TiO} 2$ were added. One flask without $\mathrm{TiO} 2$ was taken as control. Flasks were incubated at $37^{\circ} \mathrm{C}$ and Optical Density at $600 \mathrm{~nm}$ was read every hour till 8 h.

\section{Results and Discussion}

The structural characterization was performed using XRD and found to be anatase phase of $\mathrm{TiO}_{2}$ after annealing at $500^{\circ} \mathrm{C}$ in air and the crystallite sizes were approximately equal to $15 \mathrm{~nm}$ [9]. Nanomaterials exhibit strong inhibiting effect towards a broadened spectrum of bacterial strains. The inhibitory activity of $\mathrm{TiO}_{2}$ is due to the photocatalytic generation of strong oxidizing power when illuminated with UV light at wavelength of less than 385 $\mathrm{nm}$ for 30 minutes. $\mathrm{TiO}_{2}$ particles catalyze the killing of bacteria on illumination in UV light. Generation of active free hydroxyl radicals by photo excited $\mathrm{TiO}_{2}$ particles is responsible for the antibacterial activity. Doped $\mathrm{TiO}_{2}$ nanoparticles are more inhibitory when compared with the pure $\mathrm{TiO}_{2}$ nanoparticles. Doping increases the activity, since the empty sites are filled with cerium.

Fig. 1 shows the FT-IR spectra of $\mathrm{TiO}_{2}$ and Ce-doped $\mathrm{TiO}_{2}$ nanoparticles annealed at $500^{\circ} \mathrm{C}$ in air. A broad absorption band was observed between 3800 to $3000 \mathrm{~cm}^{-1}$ which is related to stretching hydroxyl $(\mathrm{O}-\mathrm{H})$ group, representing the water as moisture. A broad absorption band from 2960 to 2800 $\mathrm{cm}^{-1}$ is due to $\mathrm{C}-\mathrm{H}$ stretching vibrations.

The peak at $1626 \mathrm{~cm}^{-1}$ were indicated to stretching vibrations of $\mathrm{C}=\mathrm{O}$ which formed from TTIP and ethanol. The peak between 830 and $420 \mathrm{~cm}^{-1}$ is associated with the Ti-O stretching bands and is attributed to anatase phase of $\mathrm{TiO}_{2}$. It is clear that the sharp peak 
at $480 \mathrm{~cm}^{-1}$ has been shifted to $413 \mathrm{~cm}^{-1}$ with the doping of $\mathrm{Ce}$.

Kirby-Bauer test is depicted in Fig.2, where the zone of inhibition in $\mathrm{TiO} 2$ doped with cerium was found to be $15-18 \mathrm{~mm}$ with a concentration of $1 \mathrm{mg} / \mathrm{ml}$. For comparison, $\mathrm{TiO} 2$ was not added in another well which was taken as control.

Fig. 3 shows the Colony Forming Unit, as the concentration of metal oxides was increased; the colony growth was considerably decreased. In $1 \mathrm{mg} / \mathrm{ml}$ concentration of cerium doped $\mathrm{TiO} 2$ nanoparticles, just 38 colonies were observed but in $0.2 \mathrm{mg} / \mathrm{ml}$ concentration 214 colonies were observed whereas for pure $\mathrm{TiO} 2$ nanoparticles, 120 colonies were observed at concentration of $1.0 \mathrm{mg} / \mathrm{ml}$ and 290 colonies observed for $0.2 \mathrm{mg} / \mathrm{ml}$ concentration.

Fig.4 depicts the effect of $\mathrm{TiO} 2$ in liquid media that is the $\mathrm{TiO} 2$ nanoparticles decreased the turbidity of bacteria with increase in concentration of $\mathrm{TiO}_{2}$ nanoparticles. More the concentration of
$\mathrm{TiO} 2$ in the liquid medium, less the turbidity.

From Fig.5, it is evident that both cerium doped $\mathrm{TiO} 2$ and undoped $\mathrm{TiO} 2$ have bactericidal activity. Comparatively pure $\mathrm{TiO} 2$ has shown more bactericidal activity.

Fig.6 a shows the growth curve studies of cerium doped $\mathrm{TiO}_{2}$ nanoparticles. Concentration of $1 \mathrm{mg} / \mathrm{ml}$ showed the highest inhibitory activity which is depicted through the above graph. The elevated levels of bactericidal activity can be observed through the graph.

Fig.6 b shows the bactericidal activity of pure $\mathrm{TiO} 2$ nanoparticles which is described at different time intervals. Here too increase in bactericidal activity can be observed clearly.

Fig.7 shows the effect of $\mathrm{TiO} 2$ in solid media, as the concentration of $\mathrm{TiO}_{2}$ nanoparticles was increased, the zone of inhibition was also found to increase but not as much as the antibiotic streptomycin which was used as the control.

Table.1 Colony Forming Unit with Different Concentrations of Doped and Un-doped $\mathrm{TiO}_{2}$ Nanoparticles

\begin{tabular}{ccc}
\hline \multicolumn{2}{c}{ Number of colonies counted in petriplates with different concentrations } \\
\hline $\begin{array}{c}\text { Concentration of } \\
\text { Titanium dioxide in } \\
\text { mg/ml }\end{array}$ & $\begin{array}{c}\text { Cerium doped } \\
\text { Titanium dioxide }\end{array}$ & Pure TiO $_{\mathbf{2}}$ \\
\hline Control & 253 & 312 \\
0.2 & 214 & 290 \\
0.4 & 163 & 254 \\
0.6 & 115 & 203 \\
0.8 & 82 & 176 \\
1.0 & 38 & 120 \\
\hline
\end{tabular}


Table.2 Growth Curve Studies with Different Concentrations of Doped and Un-doped $\mathrm{TiO}_{2}$ Nanoparticles

\begin{tabular}{|c|c|c|c|c|c|c|}
\hline \multicolumn{7}{|c|}{ O.D at 600nm } \\
\hline \multirow[b]{2}{*}{$\begin{array}{c}\text { Concentration in } \\
\mu \mathrm{g} / \mathrm{ml}\end{array}$} & \multicolumn{2}{|c|}{$1^{\text {st }}$ hour } & \multicolumn{2}{|c|}{$2^{\text {nd }}$ hour } & \multicolumn{2}{|c|}{$3^{\text {rd }}$ hour } \\
\hline & $\begin{array}{l}\text { Pure } \\
\mathrm{TiO}_{2}\end{array}$ & $\begin{array}{c}\text { Doped } \\
\mathrm{TiO}_{2}\end{array}$ & $\begin{array}{l}\text { Pure } \\
\mathrm{TiO}_{2}\end{array}$ & $\begin{array}{l}\text { Doped } \\
\mathrm{TiO}_{2}\end{array}$ & $\begin{array}{l}\text { Pure } \\
\mathrm{TiO}_{2}\end{array}$ & $\begin{array}{l}\text { Doped } \\
\mathrm{TiO}_{2}\end{array}$ \\
\hline $200 \mu \mathrm{g}$ & 0.19 & 0.03 & 0.20 & 0.07 & 0.22 & 0.13 \\
\hline $400 \mu \mathrm{g}$ & 0.16 & 0.02 & 0.17 & 0.06 & 0.21 & 0.10 \\
\hline $600 \mu \mathrm{g}$ & 0.12 & 0.03 & 0.16 & 0.05 & 0.18 & 0.09 \\
\hline $800 \mu \mathrm{g}$ & 0.11 & 0.02 & 0.16 & 0.04 & 0.17 & 0.07 \\
\hline $1000 \mu \mathrm{g}$ & 0.07 & 0.01 & 0.10 & 0.02 & 0.15 & 0.07 \\
\hline \multicolumn{7}{|c|}{ O.D at 600nm } \\
\hline \multirow[b]{2}{*}{$\begin{array}{c}\text { Concentration in } \\
\mu \mathrm{g} / \mathrm{ml}\end{array}$} & \multicolumn{2}{|c|}{$4^{\text {th }}$ hour } & \multicolumn{2}{|c|}{$5^{\text {th }}$ hour } & \multicolumn{2}{|c|}{$6^{\text {th }}$ hour } \\
\hline & $\begin{array}{l}\text { Pure } \\
\mathrm{TiO}_{2}\end{array}$ & $\begin{array}{l}\text { Doped } \\
\mathrm{TiO}_{2}\end{array}$ & $\begin{array}{l}\text { Pure } \\
\mathrm{TiO}_{2}\end{array}$ & $\begin{array}{l}\text { Doped } \\
\mathrm{TiO}_{2}\end{array}$ & $\begin{array}{l}\text { Pure } \\
\mathrm{TiO}_{2}\end{array}$ & $\begin{array}{l}\text { Doped } \\
\mathrm{TiO}_{2}\end{array}$ \\
\hline $200 \mu \mathrm{g}$ & 0.25 & 0.15 & 0.28 & 0.18 & 0.29 & 0.20 \\
\hline $400 \mu \mathrm{g}$ & 0.24 & 0.13 & 0.27 & 0.14 & 0.28 & 0.15 \\
\hline $600 \mu \mathrm{g}$ & 0.21 & 0.10 & 0.23 & 0.11 & 0.23 & 0.13 \\
\hline $800 \mu \mathrm{g}$ & 0.19 & 0.09 & 0.20 & 0.10 & 0.21 & 0.12 \\
\hline $1000 \mu \mathrm{g}$ & 0.16 & 0.06 & 0.17 & 0.07 & 0.17 & 0.08 \\
\hline
\end{tabular}

Fig.1 FTIR Spectra of (a) Un-doped and (b) Ce-doped $\mathrm{TiO}_{2}$ Nanoparticles

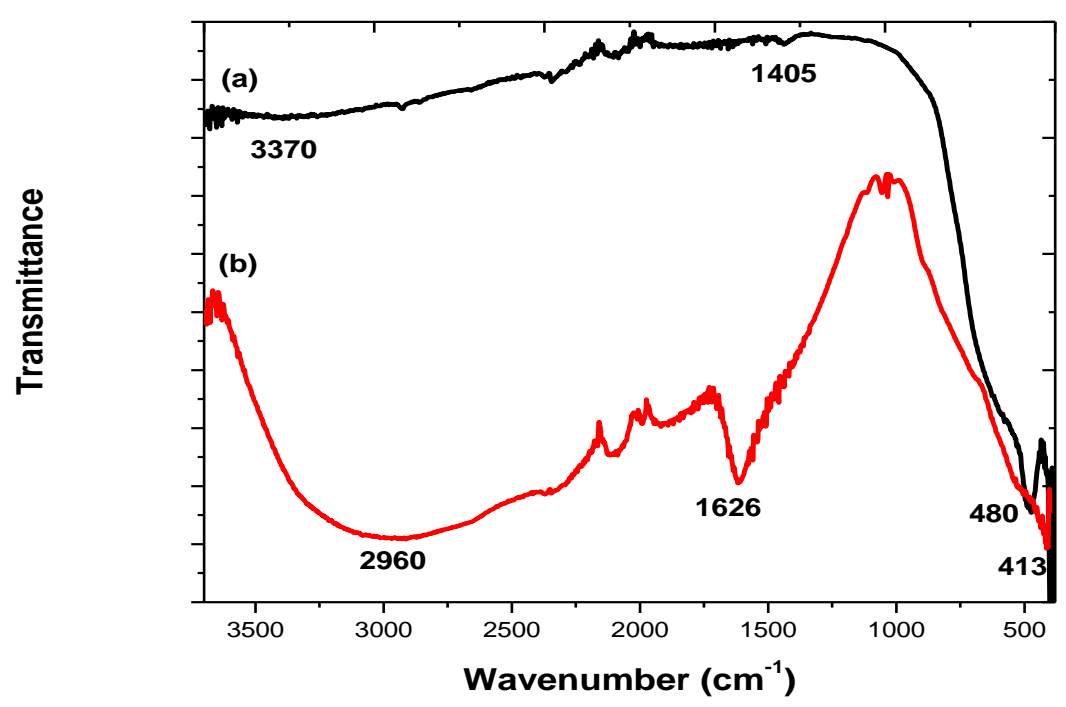


Fig.2 Kirby-Bauer Test of Ce-doped (A) and Un-doped (B) $\mathrm{TiO}_{2} \mathrm{Nanoparticles}$
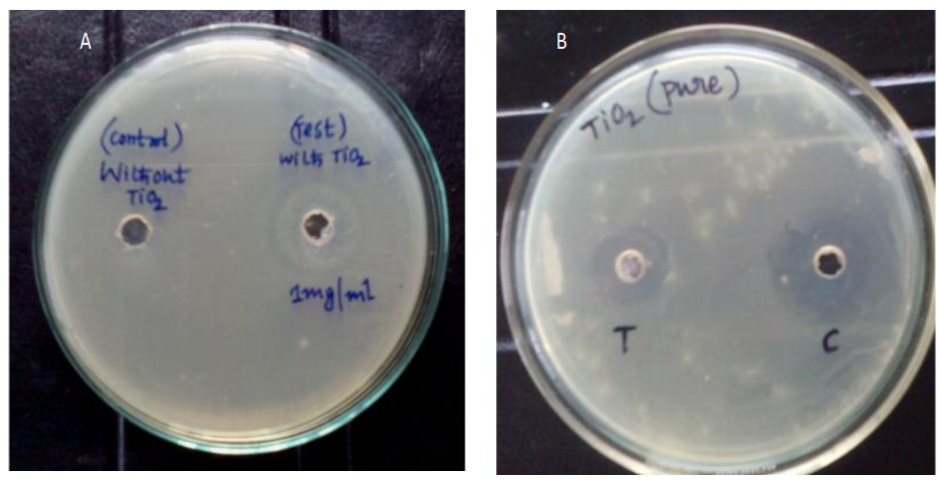

Fig.3 Colony Forming Unit of Ce-doped (A) and Un-doped (B) $\mathrm{TiO}_{2} \mathrm{Nanoparticles}^{-}$
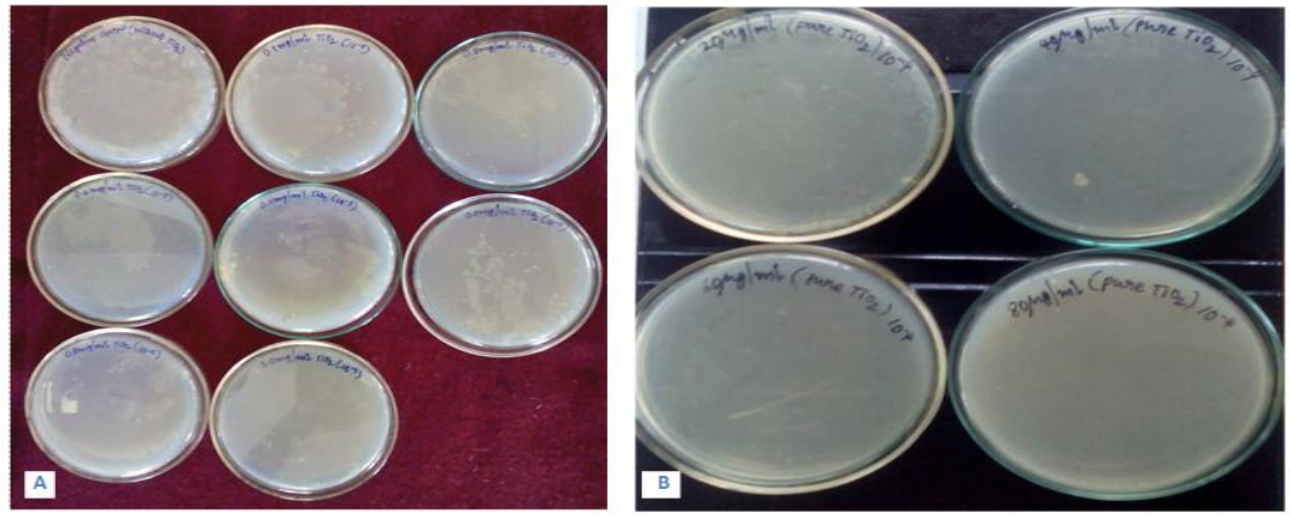

Fig.4 Effect of $\mathrm{TiO}_{2}$ in Liquid Media of Ce-doped (A) and Un-doped (B) $\mathrm{TiO}_{2} \mathrm{Nanoparticles}$
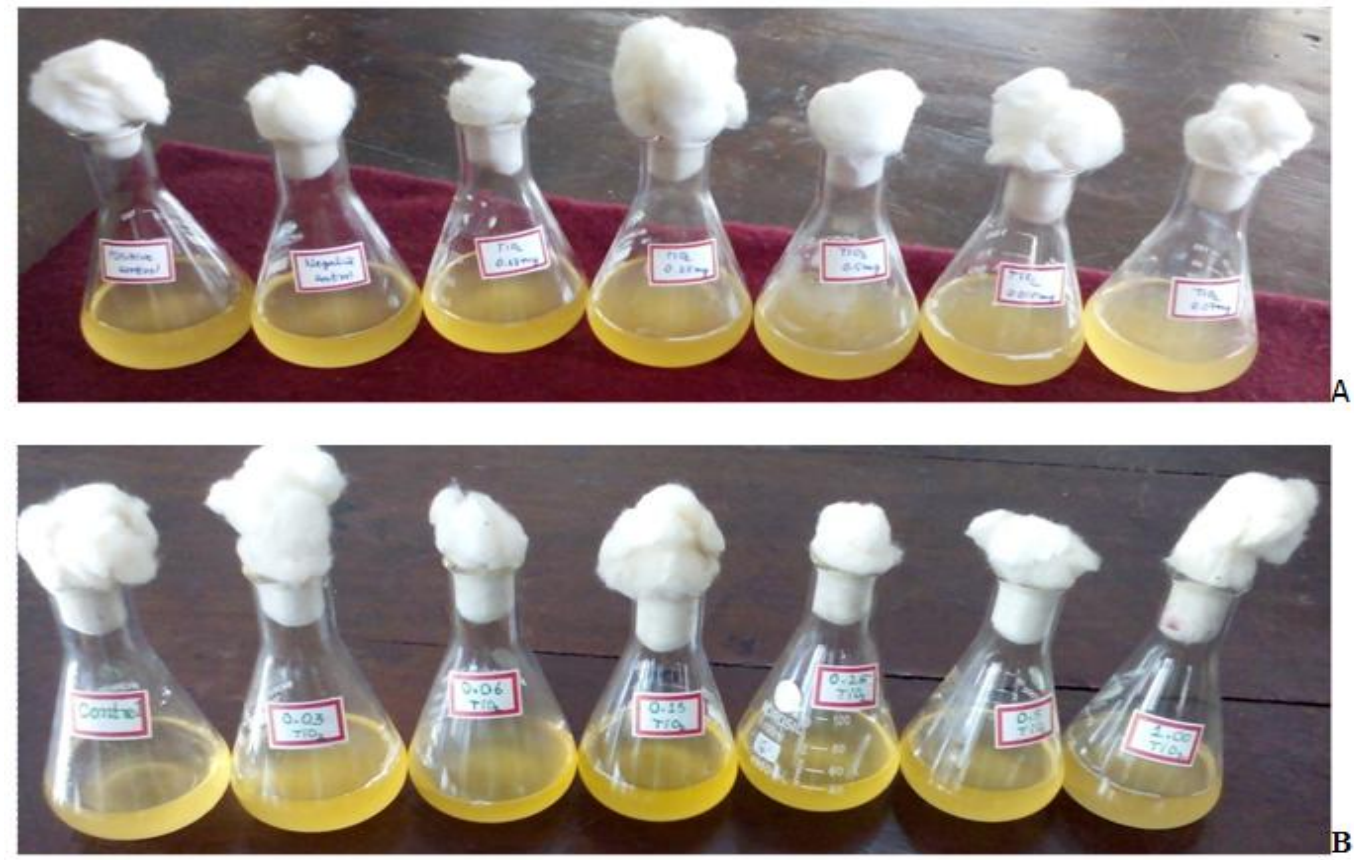
Fig.5 Comparative Antibacterial Activity of Doped and Undoped $\mathrm{TiO}_{2}$ Nanoparticles in Liquid Media

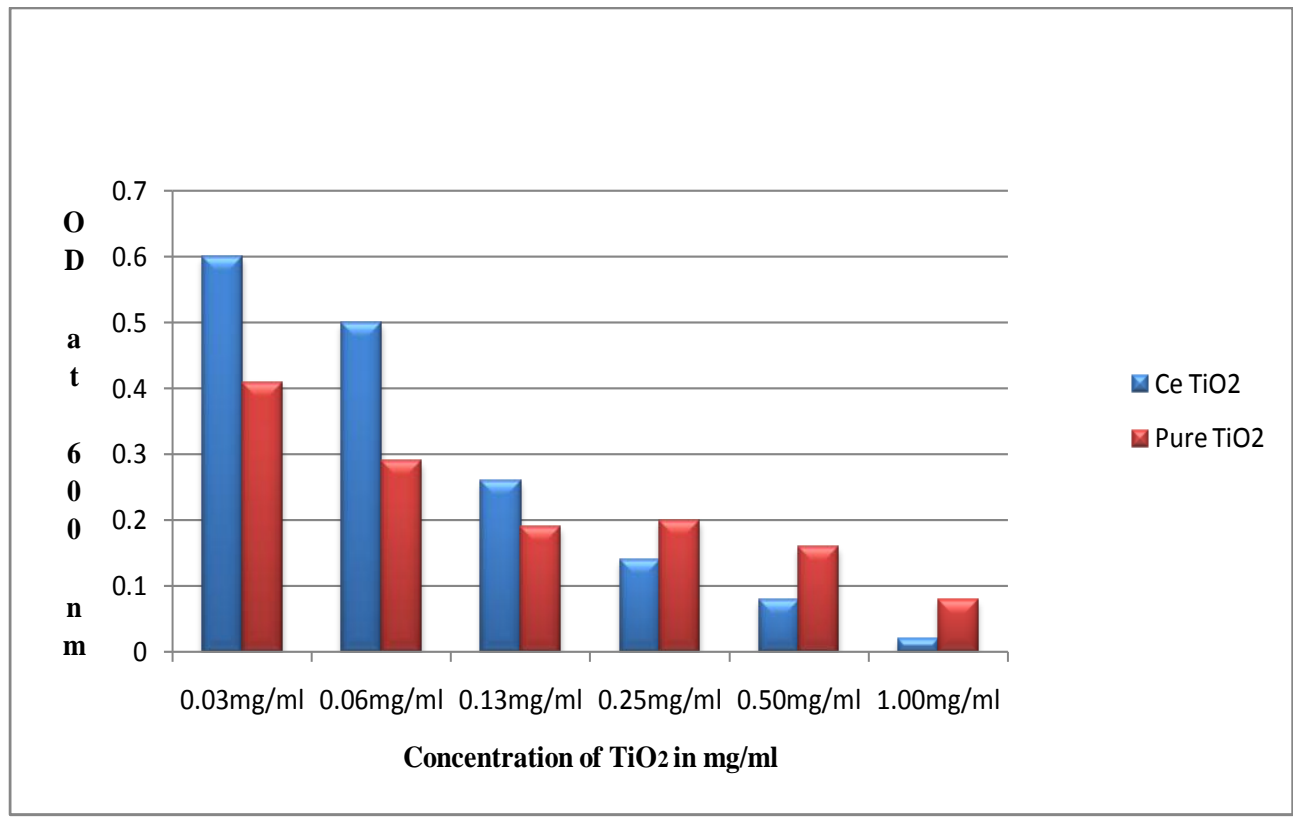

Fig.6 Growth Curve Study of E.coli in the Presence of (a) Ce-doped $\mathrm{TiO}_{2}$ Nanoparticles (b) Un-doped $\mathrm{TiO}_{2}$ Nanoparticles
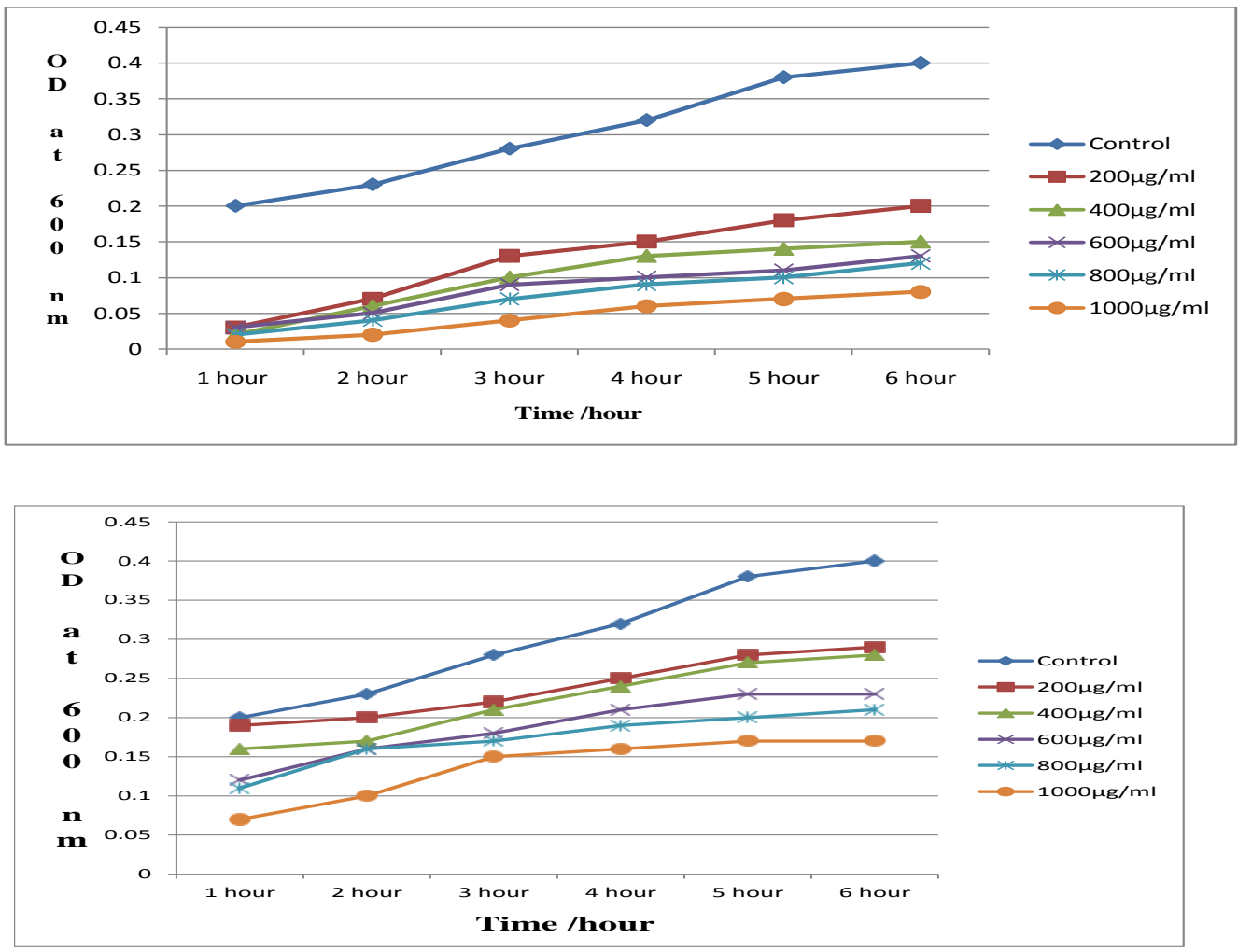
Fig.7 Effect of $\mathrm{TiO}_{2}$ in Solid Media of Ce-doped (A) and Un-doped (B) $\mathrm{TiO}_{2} \mathrm{Nanoparticles}$

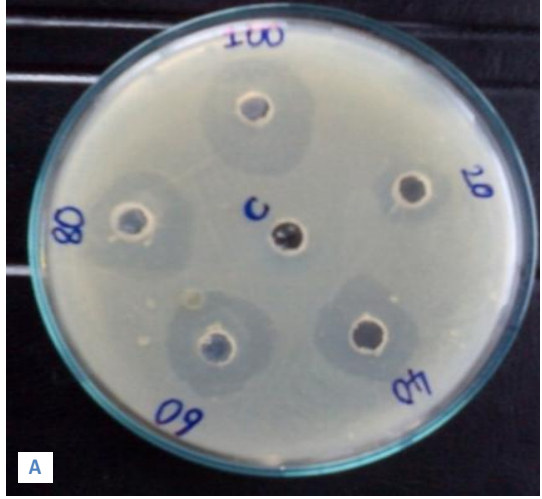

In conclusion, From the above comparative studies, Ce-TiO2 nanoparticles found to show elevated levels of bactericidal activity when performed on different relevant methods of testing antibacterial activity. The nanoparticles can be more effective when combined with antibiotics. In the coming days, $\mathrm{TiO}_{2}$ nanoparticles will play a significant role in the area of medical research for the production of effective antibiotics against different antibiotic resistant bacteria and it is the need of the hour.

\section{Acknowledgement}

The authors are thankful to Dr. K. Narasimha Rao, Chief Research Scientist and Prof. K. Rajanna, Chairman, Dept. of Instrumentation and Applied Physics, Indian Institute of Science, Bangalore for their kind support and encouragement.

\section{References}

Kiran Gupta, R.P., Singh, Ashutosh Pandey, Anjana Pandey, Beilstein 2013. J. Nanotech., 4: 345-351.

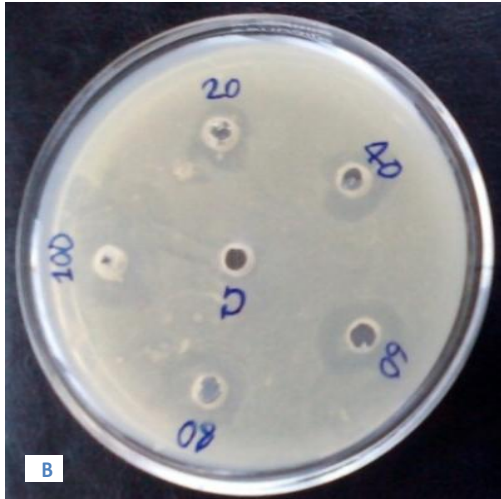

Razi Ahmad, Meryam Sardar. 2013. Int. J. Inn. Res. Sci. Engg \&Tech., 2(8): 3569-3574.

Thomas Verdier, Marie Coutand, Alexander Bertron, Christine Roques. 2014. Coatings, 4: 670-686.

Vishwas, M., Narasimha Rao, K., Arjuna Gowda, K.V., Chakradhar, R.P.S. 2011. Spectrochimica Acta Part A, 83: 614-617.

Vishwas, M., Narasimha Rao, K., Chakradhar, R.P.S., Ashok, Raichur, M. 2014. J. Mat. Sci.: Mat. Elec., 25: 4495-4500.

Vishwas, M., Narasimha Rao, K., Neelapriya, D., Ashok, M., Raichur, Chakradhar, R.P.S., Venkateswarulu, K. 2014. Proceedia Materials Sci., 5: 847-854.

Vishwas, M., Rao, K.N., Phani, A.R., Gowda, K.V.A. 2012. J. Optics, 41(1): 60-64.

Vishwas, M., Sudhir Kumar Sharma, K., Narasimha Rao, S., Mohan, K.V., Arjuna Gowda, R.P.S., Chakradhar. 2010. Modern Physics Letters B, 24: 807-816.

Vishwas, M., Sudhir Kumar Sharma, Narasimha Rao, K., Mohan, S., Arjuna Gowda, K.V., Chakradhar, R.P.S. 2009. Spectrochimica Acta Part A, 74: 839-842.

\section{How to cite this article:}

Zeeshan Ali, Bharat Raj, M. Vishwas and M. Anisa Athhar. 2016. Synthesis, Characterization

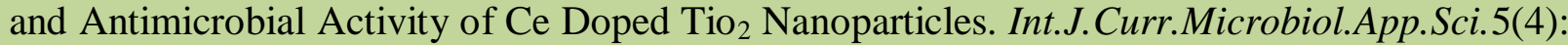
705-712. doi: http://dx.doi.org/10.20546/ijcmas.2016.504.081 